\title{
ANALISIS PROFIL HEMATOLOGI AKIBAT RADIASI PADA PETUGAS DI INSTALASI RADIOLOGI RSUD BAHTERAMAS, KENDARI
}

\author{
Arum Dian Pratiwi ${ }^{1}$ Lisnawaty $^{2}$ Jumakil ${ }^{3}$ Fifi Nirmala G. ${ }^{4}$ Nurmaladewi ${ }^{5}$ \\ 1,2,3,4,5 Fakultas Kesehatan Masyarakat Universitas Halu Oleo Kendari \\ ${ }^{1}$ arum.dian28@gmail.com 2lisnaradhiyah@gmail.com 33makildjoe@gmail.com \\ 4fifinirmala87@gmail.com ${ }^{5}$ nurmaladewi@uho.ac.id
}

\begin{abstract}
Salah satu penerapan teknologi nuklir dalam bidang kesehatan atau medik adalah pelayanan radiologi. Unit Pelayanan Radiologi merupakan salah satu instalasi penunjang medik, menggunakan sumber radiasi pengion (sinar-X) untuk mendiagnosis adanya suatu penyakit dalam bentuk gambaran anatomi tubuh yang ditampilkan dalam film radiografi. Rumah Sakit Bahteramas Sulawesi Tenggara adalah rumah sakit yang memiliki instalasi radiologi dan unit CT-scan. Tujuan penelitian ini adalah untuk mengetahui gambaran dosis radiasi yang diterima oleh pekerja instalasi radiologi dan untuk mengetahui perbedaan kadar hemoglobin, leukosit, dan trombosit pada pekerja instalasi radiologi. Penelitian ini dilakukan di Instalasi Radiologi Rumah Sakit Umum Bahteramas Kendari, Sulawesi Tenggara. Variabel dalam penelitian ini adalah umur, masa kerja, dosis radiasi, kadar hemoglobin, leukosit, dan trombosit. Jumlah sampel dalam penelitian ini adalah 12 responden. Penelitian ini menggunakan analisis data secara deskriptif dan secara analitik (uji beda). Hasil Penelitian menunjukkan bahwa dosis radiasi yang diterima oleh petugas (dari hasil TLD badge) dalam kurun waktu 3 bulan masih jauh di bawah Nilai Batas Dosis yang diperkenankan. Rata-rata dosis radiasi yang diterima adalah 0,2766 mSv dengan nilai $\min$-max $=0,2399-0,3525 \mathrm{mSv}$. Tidak terdapat perbedaan kadar hemoglobin ( $p$-value $=0,894)$, kadar leukosit $(p$-value $=0144)$, dan kadar trombosit $(p$-value $=0,506)$ yang bermakna pada pekerja instalasi radiologi baik yang kontak langsung maupun yang tidak kontak langsung di RSUD Bahteramas Kendari.
\end{abstract}

Kata kunci: Dosis Radiasi, Hemoglobin, Leukosit, Trombosit, Umur, Masa Kerja, RSUD Bahteramas

\begin{abstract}
An application of nuclear technology in the health or medical field is radiology services. Radiology Instalation is one of the medical support installations, using a source of ionizing radiation (X-rays) to diagnose the existence of a disease in the form of an anatomical picture of the body that is displayed on a radiographic film. Bahteramas Hospital in Southeast Sulawesi is a hospital that has a radiology installation and CT-scan unit. The study aimed to determine the description of radiation doses received by radiology installation workers and to determine differences in hemoglobin, leukocyte and platelet levels in radiology installation officers. The type of study was observational analitic with cross sectional approach. The variables in this study were age, years of service, radiation dose, hemoglobin, leukocyte, and platelet levels. The number of samples in this study were 12 respondents. The study used descriptive and analytical data analysis (different test). The results showed that the radiation dose received by the officer (from the TLD badge) within 3 months was far below the allowable Dose Limit Value. The average radiation dose received is $0.2766 \mathrm{mSv}$ with min-max value $=0.2399$ $0.3525 \mathrm{mSv}$. There were no differences in hemoglobin levels ( $p$ value $=0.894$ ), leukocyte levels $(p$ value $=$ 0144 ), and platelet levels ( $p$ value $=0.506$ ) which were significant in radiology installation workers both in direct and non-direct contact at the Bahteramas General Hospital in Kendari.
\end{abstract}

Keywords: Radiation Dose, Hemoglobin, Leukocytes, Platelets, Age, Working Period, Bahteramas Hospital 


\section{PENDAHULUAN}

Radiasi saat ini telah banyak dimanfaatkan di berbagai bidang, salah satunya dalam bidang kesehatan. Unit pelayanan radiologi merupakan bagian dari instalasi penunjang medik yang menggunakan sumber radiasi pengion untuk mendiagnosis adanya suatu penyakit dalam bentuk gambaran anatomi tubuh yang ditampilkan dalam film radiografi. Pelayanan radiologi harus memperhatikan aspek keselamatan kerja radiasi. Pemerintah telah menerbitkan beberapa peraturan yang bertujuan untuk melakukan perlindungan terhadap radiasi ionisasi pada radiografer, pasien maupun orang yang ada di sekitar lingkungan tempat kerja. Peraturan tersebut antara lain Peraturan Pemerintah Nomor 33 tahun 2007 tentang keselamatan radiasi pengion dan keamanan sumber radioaktif ${ }^{1}$.

Efek biologi utama yang terjadi manusia sebagai akibat radiasi pengion adalah kerusakan sistem hemopoitik dan limfatik. Telah diketahui pula irradiasi seluruh tubuh pada manusia akan menyebabkan gangguan pada sel darah yaitu dengan menurunnya produksi sel darah yang disebabkan karena terhambatnya mitosis pada sel induk dalam sumsum tulang dan sistem limfotik. Derajat penurunan jumlah sel darah perifer manusia akibat sinar $\mathrm{X}$ maupun sinar gamma ternyata bergantung pada besar dosis yang diterima ${ }^{2}$.

Indikator hematopoetik yang umum digunakan sebagai indikasi pajanan radiasi adalah hitung jenis lekosit, hitung limfosit absolut, neutrofil, pletelet, dan sel darah merah. Perhitungan sel darah banyak digunakan secara umum karena hitung sel darah telah digunakan secara rutin dan disamping itu banyak personil telah terlatih dalam menanganinya secara cepat. Gangguan sistem hematopoitik karena paparan radiasi mengakibatkan sejumlah sel darah menurun sesuai dengan sensitivitas dan angka harapan hidup, dimana limfosit yang pertama bereaksi, diikuti granulosit, trombosit dan terakhir etritrosit ${ }^{1}$.

Interaksi radiasi pengion dengan tubuh manusia akan mengakibatkan terjadinya efek kesehatan. Efek kesehatan ini, yang dimulai dengan peristiwa yang terjadi pada tingkat molekuler, akan berkembang menjadi gejala klinis. Sifat dan keparahan gejala, dan juga waktu kemunculannya, sangat bergantung pada jumlah dosis radiasi yang diserap dan laju penerimaannya.

Penyerapan energy dari radiasi ke dalam bahan biologic dapat menyebabkan eksitasi atau ionisasi. Eksitasi adalah munculnya satu electron dalam suatu atom atau molekul pada tingkat energy yang lebih tinggi tanpa pengusiran electron. Jika radiasi memiliki cukup energy untuk mengusir satu atau lebih electron orbitasl dari atom atau molekul disebut ionisasi dan radiasi tersebut disebut radiasi ionisasi (pengion) dimana karakteristiknya adalah pelepasan secara local sejumlah besar energy. Efek biologic radiasi menghasilkan kerusakan pada sel yang secara lebih mendetail berupa kerusakan DNA yang merupakasn sasaran utama pajanan radiasi. Ketika suatu bentuk radiasi baik sinar $\mathrm{X}$, gamma atau partikel bermuatan mengenai atau berasa dalam suatu jaringan tubuh organism, maka ada kemungkinan akan berinteraksi langsung dengan sel atau sub seluler dengan sasaran kritis dalam sel seperti inti sel yang mengandung kromosom. Atom dalam sasaran dapat tereksitasi atau terionisasi dan akan memulai serangkaian kejadian yang mengarah ke perubahan biologic. Radiasi juga dapat berinteraksi dengan atom atau molekul lain (terutama air) untuk menghasilkan radikal bebas yang dapat berdifusi lebih jauh untuk mencapai dan melukai sasaran kritik dalam sel. Semua perubahan yang terjadi akibat interaksinya dengan radiasi pengion dalam materi biologic dapat digunkan untuk menentukan besarnya dosis radiasi ${ }^{3}$.

Petugas radiologi mempunyai risiko terpapar radiasi, dengan efek utama yaitu kerusakan system hemopoetik dan limfatik yang dapat menimbulkan kerusakan somatik dan kerusakan genetik. Risiko kerusakan somatik berupapenyakit kanker akan dialami langsung oleh orang yang sel somatiknya terkena penyinaran. Risiko dari kerusakan genetik tidak dialami oleh yang bersangkutan, melainkan keturunan orang tersebut yang akan untuk menderita cacat genetis. Indikator hematopoitik meliputi hitung limfosit absolut, neutrofil, platelet dan sel darah merah ${ }^{4}$.

Besarnya dosis radiasi yang diterima oleh pekerja radiasi tidak boleh melebihi 50 milisievert per tahun, sedangkan besarnya dosis radiasi yang diterima oleh masyarakat pada umumnya tidak boleh lebih dari 5 milisievert per tahun ${ }^{5}$. Berdasarkan Perka Bapeten No 4 Tahun 2013 pasal 15 disebutkan bahwa "Dosis Efektif rata-rata sebesar $20 \mathrm{mSv}$ (duapuluh milisievert) per tahun dalam periode 5 (lima) tahun, sehingga Dosis yang terakumulasi dalam 5 (lima) tahun tidak boleh melebihi 100 mSv (seratus milisievert)" Berdasarkan peraturan tersebut dapat dipahami bahwa dosis efektif rata-rata yang diperbolehkan bagi pekerja radiasi adalah $20 \mathrm{mSv}$.

Dalam Komisi Internasional tahun 1990 tertera bahwa pengaruh sinar- $X$ dapat menyebabkan kerusakan haemopoetik (kelainan darah) seperti: Anemia, Leukemia dan Leukopeni yaitu menurunnya jumlah leukosit (dibawah normal atau < $6.000 \mathrm{m3}$ ). Pada manusia dewasa, leukosit dapat dijumpai sekitar 7000 sel per mikroliter darah ${ }^{6}$.

Sejumlah komponen biologi akan mengalami perubahan setelah pajanan radiasi sebagai akibat 
langsung dari kerusakan radiasi dan sebagai respon untuk proses perbaikan dan regenerasi sel. Indikator hematopoitik yang umum digunakan sebagai indikasi pajanan radiasi adalah hitung limfosit absolut, neutrofil, pletelet dan sel darah merah. Adapun jenis sampel biologik yang dapat dipergunakan untuk pengkajian dosis radiasi yang diterima oleh pekerja radiasi maupun korban kecelakaan radiasi antara lain darah (leukosit), sperma, rambut dan urine ${ }^{6}$.

Adapun nilai rujukan yang digunakan untuk menilai normal tidaknya kadar hemoglobin, leukosit, dan trombosit mengacu pada nilai rujukan yang digunakan oleh Laboratorium Maxima, yaitu kadar normal $\mathrm{Hb}$ bagi pria adalah $14,0-17,4 \mathrm{~g} / \mathrm{dL}$ sedangkan wanita 12,3-15,3 g/dL, kadar leukosit normal bagi laki-laki adalah 3800-10600/uL; dan bagi perempuan adalah 3600-11000/uL, kadar trombosit normal adalah 150.000-440.000/uL.

Penelitian ini dilakukan di Instalasi Radiologi RSUD Bahteramas Kendari. Tujuan penelitian ini adalah untuk mengetahui gambaran dosis radiasi pada TLD badge yang diterima oleh petugas instalasi dan untuk mengetahui perbedaan kadar hemoglobin, leukosit, dan trombosit pada pekerja instalasi radiologi baik yang kontak langsung maupun yang tidak kontak langsung di RSUD Bahteramas Kendari.

\section{METODE}

Jenis penelitian ini adalah penelitian observasional dengan pendekatan analitik (komparasi). Design penelitian ini adalah cross sectional studi. Variabel dalam penelitian ini adalah jenis paparan, dosis radiasi, kadar hemoglobin, leukosit, dan trombosit. Dosis radiasi dalam penelitian ini diketahui dengan melihat data sekunder dari hasil TLD badge, sementara kadar hemoglobin, leukosit, dan trombosit menggunakan data sekunder yang telah ada disediakan. Adapun instrument yang digunakan adalah kuesioner. Penelitian ini menggunakan analisis data secara deskriptif dan analitik (komparasi) dengan uji t tidak berpasangan.

\section{HASIL DAN PEMBAHASAN}

Tabel 1. Distribusi Veriabel Penelitian

\begin{tabular}{lcccccc}
\hline Variabel & Kategori & $\mathbf{n}$ & $\mathbf{\%}$ & Min & Max & Mean \\
\hline Umur & $31-35$ & 3 & 25 & 32 & 43 & 37,92 \\
(tahun) & $36-40$ & 6 & 50 & & & \\
& $41-45$ & 3 & 25 & & & \\
\hline Masa & $1-5$ & 1 & 8,33 & 5 & 16 & 10,58 \\
kerja & $6-10$ & 5 & 41,67 & & & \\
(tahun) & $11-15$ & 6 & 50 & & & \\
\hline Jenis & Dokter & 1 & 8,3 & & & \\
Pekerjaan & $\begin{array}{l}\text { Radiologi } \\
\text { Radiograf }\end{array}$ & 5 & 41,7 & & & \\
& er & & & & & \\
& Fisikawan & 2 & 16,7 & & & \\
\hline
\end{tabular}

\begin{tabular}{|c|c|c|c|c|c|c|}
\hline & $\begin{array}{c}\text { Medik } \\
\text { Staf } \\
\text { Adminstra } \\
\text { si }\end{array}$ & 4 & 33,3 & & & \\
\hline Status Gizi & $\begin{array}{l}\text { Kurus } \\
\text { Normal } \\
\text { Gemuk }\end{array}$ & $\begin{array}{l}2 \\
9 \\
1\end{array}$ & $\begin{array}{c}16,7 \\
75 \\
8,3\end{array}$ & $\begin{array}{c}17,9 \\
9\end{array}$ & $\begin{array}{c}25,7 \\
7\end{array}$ & 22,14 \\
\hline $\begin{array}{l}\text { Dosis } \\
\text { Radiasi } \\
(\mathrm{mSv})\end{array}$ & $\begin{array}{l}>N B D \\
\leq N B D\end{array}$ & $\begin{array}{l}0 \\
1 \\
2\end{array}$ & $\begin{array}{c}0 \\
100\end{array}$ & $\begin{array}{c}0,23 \\
99\end{array}$ & $\begin{array}{c}0,35 \\
25\end{array}$ & $\begin{array}{c}0,276 \\
6\end{array}$ \\
\hline $\begin{array}{l}\text { Jenis } \\
\text { Paparan }\end{array}$ & $\begin{array}{l}\text { Langsung } \\
\text { Tidak } \\
\text { Langsung }\end{array}$ & $\begin{array}{l}8 \\
4\end{array}$ & $\begin{array}{l}66,7 \\
33,3\end{array}$ & & & \\
\hline $\begin{array}{l}\text { Kadar Hb } \\
\text { (gr/dL) }\end{array}$ & $\begin{array}{c}\text { Normal } \\
\text { Tidak } \\
\text { Normal }\end{array}$ & $\begin{array}{l}1 \\
1 \\
1\end{array}$ & $\begin{array}{c}91,67 \\
8,33\end{array}$ & $\begin{array}{c}10,3 \\
3\end{array}$ & 16,8 & 13,98 \\
\hline $\begin{array}{l}\text { Kadar } \\
\text { Leukosit } \\
\left(10^{3} / \mathrm{uL}\right)\end{array}$ & $\begin{array}{c}\text { Normal } \\
\text { Tidak } \\
\text { normal }\end{array}$ & $\begin{array}{l}1 \\
2 \\
0\end{array}$ & $\begin{array}{c}100 \\
0\end{array}$ & 4,67 & $\begin{array}{c}10,4 \\
1\end{array}$ & 7,122 \\
\hline $\begin{array}{l}\text { Kadar } \\
\text { Trombosit } \\
\left(10^{3} / \mathrm{uL}\right)\end{array}$ & $\begin{array}{c}\text { Normal } \\
\text { Tidak } \\
\text { normal }\end{array}$ & $\begin{array}{l}1 \\
2 \\
0\end{array}$ & $\begin{array}{c}100 \\
0\end{array}$ & 225 & 361 & 305,4 \\
\hline
\end{tabular}

\section{Uji Normalitas Data}

Tabel 2. Uji Normalitas Data

\begin{tabular}{llccc}
\hline & Jenis & \multicolumn{3}{c}{ Shapiro-Wilk } \\
\cline { 3 - 5 } & Paparan & Statistic & Df & Sig. \\
\hline Kadar & Langsung & 0,948 & 8 & 0,691 \\
Hemoglobin & $\begin{array}{c}\text { Tidak } \\
\text { langsung }\end{array}$ & 0,820 & 4 & 0,144 \\
\hline Kadar Leukosit & $\begin{array}{c}\text { Langsung } \\
\text { Tidak } \\
\text { langsung }\end{array}$ & 0,979 & 8 & 0,958 \\
\hline Kadar & $\begin{array}{c}\text { Langsung } \\
\text { Trombosit }\end{array}$ & 0,915 & 4 & 0,330 \\
\hline & $\begin{array}{c}\text { Tidak } \\
\text { langsung }\end{array}$ & 0,863 & 4 & 0,269 \\
\hline
\end{tabular}

Berdasarkan uji normalitas data (Shapiro-Wilk; karena jumlah data $<50$ data), maka diketahui bahwa data kadar hemogobin, leukosit, dan trombosit baik yang terpapar langsung maupun tidak langsung memiliki data yang terdistribusi normal. Hal ini diketahui dari nilai Sig. (Shapiro-Wilk) yaitu kadar hemoglobin terpapar langsung adalah 0,691>0,05, kadar hemoglobin terpapar tidak langsung adalah 0,144>0,05, kadar leukosit terpapar langsung adalah 0,958 >0,05, kadar leukosit terpapar tidak langsung adalah 0,330>0,05, kadar trombosit terpapar langsung adalah 0,393>0,05, kadar trombosit terpapar tidak langsung adalah 0,269 > 0,05 . Berdaraskan tabel 2 diketahui bahwa data kadar hemoglobin, leukosit, dan trombosit memenuhi syarat untuk diuji dengan uji t tidak berpasangan. 
Preventif Journal
Vol.4/No. 2/ April/2020; p-ISSN 2540-8283 e-ISSN: 2620-3294,

\section{Uji t tidak berpasangan}

Tabel 3. Distribusi Status Hemoglobin Responden berdasarkan Jenis Paparan di Instalasi Radiologi RSUD Bahteramas Kendari 2019

\begin{tabular}{cccccccc}
\hline \multirow{2}{*}{$\begin{array}{c}\text { Jenis } \\
\text { Paparan }\end{array}$} & \multicolumn{3}{c}{ Status Hemoglobin } & \multicolumn{2}{c}{ Total } \\
\cline { 2 - 6 } & \multicolumn{2}{c}{ Normal } & \multicolumn{4}{c}{$\begin{array}{c}\text { Tidak } \\
\text { Normal }\end{array}$} \\
\cline { 2 - 7 } & $\mathbf{n}$ & $\%$ & $\mathbf{n}$ & $\mathbf{\%}$ & $\mathbf{n}$ & $\mathbf{\%}$ \\
\hline $\begin{array}{c}\text { Terpapar } \\
\text { Langsung }\end{array}$ & 7 & 87,5 & 1 & 12,5 & 8 & 100 \\
\hline $\begin{array}{l}\text { Terpapar } \\
\text { tidak } \\
\text { langsung }\end{array}$ & 4 & 100 & 0 & 0 & 4 & 100 \\
\hline Total & 11 & 91,67 & 1 & 8,33 & 12 & 100 \\
\hline
\end{tabular}

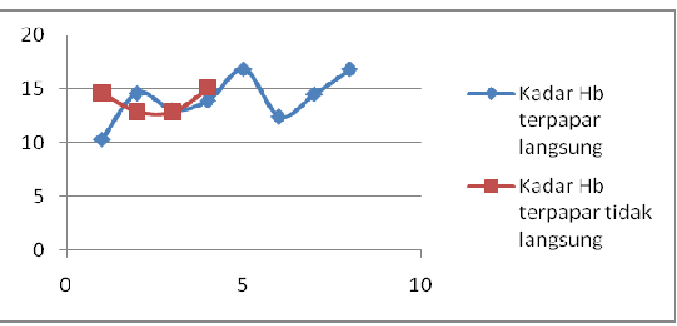

Gambar 1. Grafik Kadar Hemoglobin pada Petugas yang Terpapar Langsung dengan yang Tidak Terapapar Langsung

Tabel 4. Distribusi Status Leukosit Responden berdasarkan Jenis Paparan di Instalasi Radiologi RSUD Bahteramas Kendari 2019

\begin{tabular}{|c|c|c|c|c|c|c|}
\hline \multirow{3}{*}{$\begin{array}{c}\text { Jenis } \\
\text { Paparan }\end{array}$} & \multicolumn{4}{|c|}{ Status Leukosit } & \multirow{2}{*}{\multicolumn{2}{|c|}{ Total }} \\
\hline & \multicolumn{2}{|c|}{ Normal } & \multicolumn{2}{|c|}{$\begin{array}{c}\text { Tidak } \\
\text { Normal }\end{array}$} & & \\
\hline & $n$ & $\%$ & $\mathrm{n}$ & $\%$ & n & $\%$ \\
\hline $\begin{array}{l}\text { Terpapar } \\
\text { Langsung }\end{array}$ & 8 & 100 & 0 & 0 & 8 & 100 \\
\hline $\begin{array}{l}\text { Terpapar } \\
\text { tidak } \\
\text { langsung }\end{array}$ & 4 & 100 & 0 & 0 & 4 & 100 \\
\hline Total & 12 & 100 & 0 & c & 12 & 100 \\
\hline \multicolumn{7}{|l|}{12} \\
\hline 10 & & & & \multirow{3}{*}{\multicolumn{3}{|c|}{$\begin{array}{c}\rightarrow-\text { kadarLeukosit } \\
\text { terpapar } \\
\text { langsung } \\
\rightarrow-\text { - kadar leukosit } \\
\text { terpapar tidak } \\
\text { langsung }\end{array}$}} \\
\hline $\begin{array}{l}4 \\
2\end{array}$ & & & & & & \\
\hline 0 & & ' & & & & \\
\hline 0 & & 5 & & & & \\
\hline
\end{tabular}

Gambar 2. Grafik Kadar Leukosit pada Petugas yang Terpapar Langsung dengan yang Tidak Terapapar Langsung

Tabel 5. Distribusi Status Trombosit Responden berdasarkan Jenis Paparan di Instalasi Radiologi RSUD Bahteramas Kendari 2019

\begin{tabular}{|c|c|c|c|c|c|c|}
\hline \multirow{3}{*}{$\begin{array}{c}\text { Jenis } \\
\text { Paparan }\end{array}$} & \multicolumn{4}{|c|}{ Status Trombosit } & \multicolumn{2}{|c|}{ Total } \\
\hline & \multicolumn{2}{|c|}{ Normal } & \multicolumn{2}{|c|}{$\begin{array}{c}\text { Tidak } \\
\text { Normal }\end{array}$} & & \\
\hline & $\mathbf{n}$ & $\%$ & $\mathrm{n}$ & $\%$ & $\mathbf{n}$ & $\%$ \\
\hline $\begin{array}{l}\text { Terpapar } \\
\text { Langsung }\end{array}$ & 8 & 100 & 0 & 0 & 8 & 100 \\
\hline $\begin{array}{l}\text { Terpapar } \\
\text { tidak } \\
\text { langsung }\end{array}$ & 4 & 100 & 0 & 0 & 4 & 100 \\
\hline Total & 12 & 100 & 0 & 0 & 12 & 100 \\
\hline
\end{tabular}

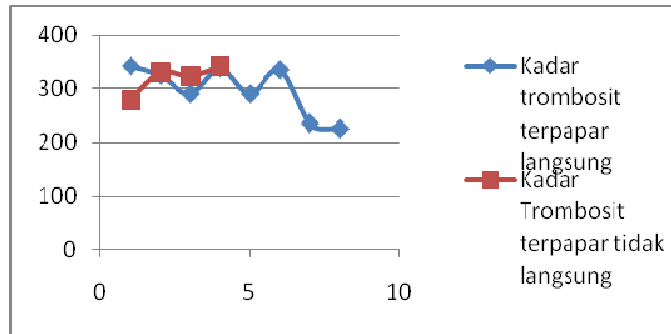

Gambar 3. Grafik Kadar Trombosit pada Petugas yang Terpapar Langsung dengan yang Tidak Terapapar Langsung

Tabel 6. Hasil Uji t tidak berpasangan

\begin{tabular}{|c|c|c|c|c|}
\hline & & \multicolumn{2}{|c|}{$\begin{array}{c}\text { Levene's Test for } \\
\text { Equality of } \\
\text { Variances }\end{array}$} & \multirow{2}{*}{$\begin{array}{c}\begin{array}{c}\mathrm{t} \text {-test for } \\
\text { Equality of } \\
\text { Means }\end{array} \\
\text { Sig. (2-tailed) }\end{array}$} \\
\hline & & $\mathrm{F}$ & Sig. & \\
\hline \multirow[t]{2}{*}{$\begin{array}{l}\text { Kadar } \\
\text { Hemoglobin }\end{array}$} & $\begin{array}{l}\text { Equal } \\
\text { variances } \\
\text { assumed }\end{array}$ & 0,958 & 0,351 & 0,894 \\
\hline & $\begin{array}{l}\text { Equal } \\
\text { variances } \\
\text { not } \\
\text { assumed }\end{array}$ & & & 0,869 \\
\hline \multirow[t]{2}{*}{ Kadar Leukosit } & $\begin{array}{l}\text { Equal } \\
\text { variances } \\
\text { assumed }\end{array}$ & 0,018 & 0,895 & 0,144 \\
\hline & $\begin{array}{l}\text { Equal } \\
\text { variances } \\
\text { not } \\
\text { assumed }\end{array}$ & & & 0,143 \\
\hline \multirow[t]{2}{*}{$\begin{array}{l}\text { Kadar } \\
\text { Trombosit }\end{array}$} & $\begin{array}{l}\text { Equal } \\
\text { variances } \\
\text { assumed }\end{array}$ & 2,122 & 0,176 & 0,506 \\
\hline & $\begin{array}{l}\text { Equal } \\
\text { variances } \\
\text { not } \\
\text { assumed }\end{array}$ & & & 0.424 \\
\hline \multicolumn{5}{|c|}{$\begin{array}{l}\text { Dosis radiasi adalah jumlah radiasi yang } \\
\text { terdapat dalam medan radiasi atau jumlah energi } \\
\text { radiasi yang diserap atau diterima oleh materi yang } \\
\text { dilaluinya (7). Berdasarkan hasil penelitian diketahui } \\
\text { bahwa dosis paparan radiasi yang diterima oleh }\end{array}$} \\
\hline
\end{tabular}


seluruh pekerja instalasi radiologi RSUD Bahteramas dalam penelitian ini berkisar antara 0,2399-0,3525 (mSv) dalam kurun waktu pemakaian September 2018 hingga November 2018 (3 bulan). Berdasarkan peraturan Bapeten Nomor 4 Tahun 2013 menyebutkan bahwa Nilai Batas Dosis (NBD) Radiasi yang diperbolehkan adalah $20 \mathrm{mSv}$ per tahun, maka akumulasi yang diizinkan dalam jangka waktu 3 bulan dapat diasumsikan adalah $5 \mathrm{mSv}$ per tiga bulan. Berdasarkan data sekunder yang diperoleh, dosis yang diterima paling tinggi adalah $0,3525 \mathrm{mSv}$, jadi nilai dosis paparan yang diterima oleh semua pegawai di Instalasi Radiologi RSUD Bahteramas masih tergolong aman atau dibawah Nilai Batas Dosis yang ditetapkan.

Penelitian ini sejalan dengan hasil penelitian Johiroh, dkk (2015), juga menemukan bahwa dosis petugas radiologi di Rumah Sakit Penyakit Infeksi (RSPI) Prof. Dr. Sulianti Saroso Tahun 2014-2015 masih di bawah Nilai Batas Dosis (NBD) yang ditetapkan, yaitu 1,1 $\mathrm{msv} /$ tahun (NBD 20 $\mathrm{mSv} /$ tahun $)^{4}$. Hasil penelitian ini juga sejalan dengan hasil penelitian Mauliku (2019) yang menemukan bahwa paparan radiasi yang diterima oleh pekerja radiologi RS Purwakarta juga masih di bawah NBD per periode ( $<5 \mathrm{mSv} /$ perode), yaitu paparan minimal 0,01 $\mathrm{mSv}$ dan maksimal 0,13 $\mathrm{mSv}^{8}$.

Hemoglobin $(\mathrm{Hb})$ adalah molekul protein (pembawa oksigen) yang terdapat dalam sel darah merah. Dengan adanya $\mathrm{Hb}$ ini, sel darah merah membawa oksigen dari paru-paru ke seluruh jaringan tubuh, dan membawa karbon dioksida dari jaringan kembali ke paru-paru. Biasanya, hemoglobin diperiksa sebagai bagian dari tes Hitung Darah Lengkap (CBC). Kadar hemoglobin dinyatakan sebagai jumlah hemoglobin dalam g / dL (gram per desiliter) darah (Honestdocs, 2019). Kadar normal Hb bagi pria adalah 14,0 - 17,4 g/dL sedangkan wanita 12,3-15,3 $\mathrm{g} / \mathrm{dL}$ (mengacu dari standar Laboratorium Maxima Kendari).

Leukosit merupakan sel darah yang melindungi tubuh terhadap kuman-kuman penyakit yang menyerang tubuh dengan cara fagosit, menghasilkan antibodi. Leukosit terdiri atas limfosit, monosit, basofil, neutrofil/heterofil dan eosinofil. Perubahan jumlah leukosit dalam sirkulasi darah dapat diartikan sebagai timbulnya agen penyakit, peradangan, penyakit auto imun atau reaksi alergi ${ }^{9}$.

Leukosit paling sedikit dalam tubuh jumlahnya sekitar 4.000-11.000/mm3. Berfungsi untuk melindungi tubuh dari infeksi. Karena itu, jumlah leukosit tersebut berubah-ubah dari waktu ke waktu, sesuai dengan jumlah benda asing yang dihadapi dalam batas-batas yang masih dapat ditoleransi tubuh tanpa menimbulkan gangguan fungsi ${ }^{10}$.

Trombosit berperan penting dalam usaha tubuh untuk mempertahankan jaringan bila terjadi luka. Trombosit ikut serta dalam menutup luka, sehingga tubuh tidak mengalami kehilangan darah dan terlindungi dari penyusupan benda dan sel asing 11 .

Trombositopenia adalah suatu kondisi dimana jumlah trombosit kurang dari normal yang disebabkan oleh reaksi awal obat-obatan, malignansi sumsum tulang, atau radiasi pengion yang merusak sumsum tulang. Keadaan sebaliknya disebut trombositosis, yaitu peningkatan jumlah trombosit karena pendarahan, terutama anemia karena kehilangan darah yang kronis, infeksi, pasca bedah, keganasan dan penyakit inflamasi ${ }^{12}$.

Radiasi pengion mengganggu system hemopoetik dan menyebabkan penurunan jumlah total sel darah ${ }^{13}$. Radiasi dapat berdampak buruk terhadap kesehatan tubuh. Radiasi dapat mempengaruhi sel-sel tubuh. Berdasarkan jenis sel, maka efek radiasi dapat dibedakan atas efek genetic dan efek somatic. Salah satu contoh dampak radiasi dalam efek somatic adalah penurunan jumlah sel darah ${ }^{14}$. Hemoglobin dibentuk di dalam sumsum tulang belakang. Sumsum tulang merah yang mendapat dosis tidak terlalu tinggi masih dapat memproduksi sel-sel darah, sedangkan pada dosis yang cukup tinggi akan terjadi kerusakan permanen yang berakhir dengan kematian (dosis lethal 3-5 sV). Akibat penekanan aktivitas sumsum tulang, maka orang yang terkena adiasi akan menderita: kecenderungan pendarahan dan infeksi anemia dan kekurangan $\mathrm{Hb}$, leukimia sumsum tulang ${ }^{15}$.

Berdasarkan hasil penelitian diketahui bahwa dari 12 responden, terdapat 1 responden (8,33\%) yang memiliki kadar $\mathrm{Hb}$ di luar batas normal yang ditentukan, dan 11 responden (91,67\%) yang memiliki kadar $\mathrm{Hb}$ dalam batas normal. Dan responden yang memiliki kadar $\mathrm{Hb}$ tidak normal adalah responden yang terpapar langsung dengan radiasi, dalam hal ini adalah radiographer. Berdasarkan data yang diperoleh kadar $\mathrm{Hb}$ yang tidak normal ini termasuk dalam kategori lebih rendah dari batasan normal $\mathrm{Hb}$ yang ditetapkan yaitu $10,3 \mathrm{gr} / \mathrm{dl}$. Responden ini memiliki masa kerja yang tertinggi yaitu 16 tahun.

Berdasarkan hasil penelitian diketahui bahwa dari 12 responden (100\%) diketahui bahwa seluruh responden memiliki kadar leukosit di ambang batas normal, yaitu berkisar antara 4,67 $10^{3} / \mathrm{uL}$ hingga $10,4110^{3} /$ uL. Kadar leukosit normal bagi laki-laki adalah 3800-10600/uL; dan bagi perempuan adalah 3600-11000/uL (mengacu dari standar Laboratorium Maxima Kendari).

Hasil penelitian ini sejalan dengan penelitian yang dilakukan oleh Mauliku (2019). Penelitiannya menunjukkan bahwa kadar leukosit petugas radiologi RS Purwakarta masih dalam katogori baik. Kadar 
leukosit berada pada range 4,680 $-9.970 \mathrm{~m}^{3}$. Hasil penelitian Yang dkk (2016) menunjukkan bahwa latihan fisik mungkin berfungsi sebagai faktor pelindung pada leukopenia ${ }^{17}$.

Berdasarkan hasil uji statistic dengan menggunakan uji $\mathrm{t}$ tidak berpasangan, ditemukan bahwa tidak ada perbedaan kadar $\mathrm{Hb}$ ( $\mathrm{p}$ value $=$ $0,894)$, kadar leukosit ( $p$ value $=0144)$, dan kadar trombosit ( $p$ value $=0,506)$ pada pekerja yang pekerjaannya terpapar langsung dengan radiasi dengan pekerja yang terpapar tidak langsung dengan radiasi (staf administrasi) pada instalasi radiologi di RSUD Bahteramas Kendari tahun 2019. Hal ini sejalan dengan penelitian yang dilakukan oleh Prayitno (2001) bahwa tidak terdapat perbedaan kadar $\mathrm{Hb}$ antara pekerja radioterapi dengan pekerja radiodiagnostik.

Hal ini dapat terjadi karena petugas yang terpapar langsung dengan radiasi telah diberikan perlindungan yang baik oleh manajemen RSUD Bahteramas. Perlindungan yang diberikan seperti proteksi gedung yang mumpuni, dimana semua dinding, kaca dan pintu telah dipasang tameng berbahan timbal (Pb). Logam ini sangat efektif sebagai tameng radiasi di sekeliling peralatan sinar-x dan reaktor nuklir (Mastah.org, 2019). Manajemen juga memberikan alat pelindung diri pada para petugas yang kontak langsung dengan peralatan radiasi seperti appron berbahan $\mathrm{Pb}$, kacamata anti radiasi, dan seluruh petugas di Instalasi radiologi baik dokter hingga staf administrasi diberikan alat pemantauan dosis radiasi yang digunakan setiap hari saat bekerja, yaitu TLD badge. Proteksi yang begitu baik kemungkinan dapat menjadi penyebab tidak terdapat perbedaan kadar $\mathrm{Hb}$ antara petugas yang terpapar langsung dengan yang tidak terpapar langsung ${ }^{18}$.

Hal lain yang dapat menjadi penyebab tidak berbedanya kadar $\mathrm{Hb}$ antara yang terpapar langsung dengan radiasi dengan yg tidak adalah masa kerja, pola konsumsi, gaya hidup, dan sebagainya. Dalam penelitian ini tidak mengontrol hal tersebut, sehingga dapat menjadi factor perancu antara kelompok petugas yang terpapar langsung, dengan yang tidak.

Sistem proteksi yang baik tentu saja dapat melindungi pekerja di instalasi tersebut agar selalu terjaga kesehatan dan keselamatannya dari dampak buruk radiasi. Sehingga berdasarkan hasil penelitian, kadar leukosit petugas di instalasi radiologi dalam kategori baik/normal.

\section{SIMPULAN DAN SARAN}

Berdasarkan hasil penelitian diatas dapat disimpulkan bahwa

1. Gambaran dosis radiasi dalam kurun waktu 3 bulan pada petugas di Instalasi Radiologi RSUD Bahteramas Kendari seluruhnya masih jauh di bawah Nilai Batas Dosis yang ditetapkan (20 $\mathrm{mSv} /$ tahun atau dapat dikatakan $5 \mathrm{mSv}$ untuk 3 bulan) dengan rata-rata dosis radiasi yang diterima adalah 0,2766 mSv dan dosis terendah yang diterima adalah 0,2399 mSv sedangkan yang tertinggi adalah 0,3525 mSv dalam kurun waktu 3 bulan.

2. Tidak terdapat perbedaan kadar hemoglobin $(p$-value $=0,894)$, kadar leukosit $(p$-value $=0144)$, dan kadar trombosit $(p$-value $=0,506)$ yang bermakna pada pekerja instalasi radiologi baik yang kontak langsung maupun yang tidak kontak langsung di RSUD Bahteramas Kendari.

Berdasarkan hasil penelitian ini dapat disarankan kepada pihak RSUD Bahteramas:

1. Agar dapat terus mempertahankan system proteksi yang telah dilakukan selama ini. Dan diharapkan kepada rumah sakit untuk dapat memeriksa secara berkala paparan radiasi di lingkungan Instalasi Radiologi RSUD Bahteramas Kendari dengan menggunakan Surveymeter.

2. Agar dapat untuk mengurangi paparan radiasi yang dapat berdampak buruk bagi petugas dapat diupayakan dengan system roling antar sesame petugas Instalasi Radiologi yang dapat dilakukan setiap bulan sekali. Sehingga kami menganjurkan untuk dapat menambah jumlah personil agar dapat dilakukan system roling ini.

\section{DAFTAR PUSTAKA}

1. Hidayati, L., 2012. Gambaran Hitung Jenis Leukosit pada Radiografer di Perusahaan $X$ Surabaya Tahun 2012. Fakultas Kesehatan Masyarakat Universitas Airlangga.

2. Gabriel, J.F., 1996. Fisika Kedokteran. Jakarta: EGC.

3. Lusiyanti, Y., M. Syaifudin. 2008. Penerapan Efek Interaksi Radiasi dengan Sistem Biologi sebagai Dosimeter Biologi. JFN. 2(1). 1-15.

4. Jahiroh, N. Hendrawai, M.M. Montain, 2015. Profil Hematologi dan Pemantauan Dosis Petugas Radiologi di Rumah Sakit Penyakit Infeksi (RSPI) Prof. Dr. Sulianti Saroso 2014-2015. The Indonesian Journal of Infectious Disease. Diakses $20 \quad$ Okt 2019: https://media.neliti.com/media/publications/261 799-none-934ec353.pdf

5. Arief, L.M.,2012. Higiene Industri: Radiasi Elektromagnetik. Universitas Esa Unggul: Jakarta.

6. Mayerni, A. Ahmad, Z. Abidin. 2013. Dampak Radiasi terhadap Kesehatan Pekeja Radiasi di RSUD Arifin Achmad, RS Santa Maria dan RS Awal Bros Pekanbaru. Jurnal Ilmu Lingkungan 7 (1). $114-127$.

7. Perka Bapeten No 4 Tahun 2013. Proteksi dan Keselamatan Radiasi dalam pemanfaatan tenaga Nuklir. Diakses $\quad 10 \quad$ Okt 2019 
https://jdih.bapeten.go.id/files/_000322_475.pd $f$

8. Mauliku, N.E., Ramadani. 2019. Hubungan Paparan Radiasi Sinar $X$ dengan Kadar Hematologi pada Petugas Radiologi Rumah Sakit Purwakarta. Teras Kesehatan 2(1). 26-31.

9. Lestari, S.H.A., Ismoyowati, dan M. Indradji. 2013. Kajian Jumlah Leukosit dan Diferensial Leukosit pada Berbagai Jenis Itik Lokal Betina Pakannya di Suplementasi Probiotik. J. Ilmiah Peternakan 1 (2): 699-709.

10. Sadikin, M., 2002. Biokimia Darah. Widya Medika Jakarta.

11. Sadikin, M. 2001. Pelacakan Dampak Radikal Bebas terhadap Makromolekul. Kumpulan Makalah Pelatihan:Radikal Bebas dan Antioksidan dalam Kesehatan. Fakultas Kedokteran UI. Jakarta.

12. Campbell, A. Neil, Jane B. Recee \& Mitcha

13. Lawrence G. 2002. Biologi Jilid 3 Edisi 5. Erlangga.

14. Nisa, A.K, U.P. Juswono, S. Martono, 2010. Efek Radioterapi Terhadap Produksi Sel Dahar pada Penderita Ca Mammae dan Ca Servix. Universitas Brawijaya. Diakses 5 November 2019 https://media.neliti.com/media/publications/159 942-ID-none.pdf.

15. Sucipto, C.D., 2014. Keselamatan dan Kesehatan Kerja. Gosyen Publishing: Yogyakarta.

16. Yang F., Zhou M., Gong L., Liu Z., Li DF., Li Jy., 2016. Effect of Low-Dose lonizing Radiation on Platelet And Leukocytes of Radiation Workers. $\begin{array}{lll}\text { Pubmed } \quad 37 & \text { (12). }\end{array}$ https://www.ncbi.nlm.nih.gov/pubmed/2799840 2

17. Prayitno, G. 2001. Perbedaan Kadar Hemoglobin, Jumlah Lekosit dan Jumlah Trombosit Darah Akibat Paparan Radiasi antara Petugas Radioterapi dan Petugas Radiodiagnostik. Diakses $1 \quad$ November 2019 http://eprints.undip.ac.id/8628/1/1258.pdf

18. Mastah.org, 2019. Timbal/Plumbum (Pb): Pengertian, Sifat Karakteristik dan Kegunaan. Diakses: $20 \quad$ Oktober 2019. https://www.mastah.org/timbal-plumbum-pb-pe ngertian-sifat-karakteristik-dan-kegunaan/ 